\title{
Sediment Losses in Watersheds in the Western-Center Meso-Region Rio-grandense
}

Ivan Renato Cardoso Krolow ${ }^{*}$, Danilo Dos Santos Rheinheimer', André Pellegrini', Jimmy Walter Rasche Alvarez ${ }^{3}$, Daniela da Rocha Vitória Krolow', Benkhelifa Mohammed ${ }^{4}$

'Federal University of Santa Maria, Santa Maria, Brazil

${ }^{2}$ Federal Technological University of Paraná, Curitiba, Brazil

${ }^{3}$ National University of Asuncion, San Lorenzo, Paraguay

${ }^{4}$ University A. IbnBadis of Mostaganem, Mostaganem, Algeria

*Corresponding author, e-mail: ikrolow55@gmail.com

\begin{abstract}
The permanent monitoring of sediment losses in small-paired watersheds is still incipient, especially in what concerns the search for information that combines variables that are part of an open and dynamic system. In this sense, this work investigated sediment losses in watersheds in the Western Meso-region Rio-grandense from 07/2010 to 12/2012. The auxiliary variables were composed of rainfall, surface and base flow and kinetic energy - in comparison to the morphometry of each microbasin and its use - to the concentration of suspended sediments and total sediment loss. Statistical analysis of the data was based on descriptive statistics, taking into account the indicators of cumulative, average, standard deviation, standard error and variance, as well as regression analysis. The largest mild to smooth corrugate relief area of the smallest river basins is not sufficient to provide lower superficial runoff values. The increase in rainfall directly contributes to the increase in kinetic energy, and leads to greater sediment losses in both small hydrographic basins. The larger area occupied by natural water reservoirs contributes efficiently to the reduction of suspended sediment losses. The watershed with larger area is more susceptible to the triggering of erosive processes than to the smaller area, in 8 (2010), 6 (2011) and 4 (2012) times.
\end{abstract}

Keywords: hydrological, retention, turbidity

\section{Introduction}

The use and management of production areas do not always meet criteria aligned with the conservationist view. According to Pedron et al. (2006), in southern Brazil a significant portion of family farming occupies areas of low agricultural ability and high environmental fragility as sharp declivity of slopes and shallow soils. Silva et al. (2010) discussed the lack of planning and proper use of land in agrarian reform settlements as the preservation of natural areas, generating environmental conflict classes. For Perazzoli et al. (2013) the impacts of soil use in hydrological and sediment transport conditions affect surface runoff, maximum flood flow, baseline flows, underground recharge, soil moisture and erosion and sedimentation volume. Ran et al. (2012) observed that rainfall hydrologic patterns, particularly peak intensities and durations, are of high relevance affecting runoff and sediment transport. The erosive processes are invigorated by precipitation that surpasses the capacity of infiltration, as well as by unfavorable geomorphological parameters such as relief. The knowledge of these parameters becomes necessary for planning and using a river basin, whose objective is to reduce soil losses in already established areas (Ferrari et al., 2013). Similarly, Torres et al. (2008) argued that the river basin should be considered as a planning unit due 
to its influence on the water produced as a runoff and the form and relief, acting on the rate and / or water regime and sediment rate produced. While the production of sediments in turn can generate important information about the management adopted in the watershed, in the same way, that can aid in planning and actions that aim at the mitigation of the erosive processes (Silva et al., 2010; Nyssen et al., 2009). The quantification of sediment in suspension in river basins is fundamental because it reflects the erosion rates caused by the energy of rain and flood on the different proportions of land use and types of applied managements (Minella et al., 2008). In this sense, the environmental monitoring of watersheds helps to identify changes that occur as a result of the use and occupation of soil and water, which reflect in the environmental conditions of the basin, thus increasing ecological knowledge of the ecosystem (Souza \& Gastaldini, 2014). In view of all of the above, this study aims at investigating sediment losses in watersheds in the Meso-region Rio-grandense.

\section{Material and methods}

This work was done through the monitoring of two small hydrographic basins located in the south of Brazil. The small hydrographic basins (SHB) are of a combined nature and are located in the Alvorada Agrarian Reform Settlement, in the municipality of Júlio de Castilhos, Geomorphological Region of the Planalto das Missões in the state of Rio Grande do Sul, Brazil. The lowest of the SHB was denominated by SHB 80 with area corresponding to $79.6 \mathrm{ha}$, and the largest of the SHB was denominated by SHB 140 and has an area equal to 144.5 ha. The two SHBs belong to the hydrographic basin of the Jacuí River and they were classified by the hierarchical method as third order.

The climate, according to the classification of Köppen, is of the type Cfa, subtropical humid with hot summers and without defined dry season. The average annual rainfall between 1976 and 2005 was 1.678 mm, with rainfall well distributed throughout the year. In both SHB, the predominant soil is the Argisol and to a lesser extent are the Cambisols, Neosols and Gleissolos. The average texture for the A horizon presented $67.2 \%$ of sand, $17.4 \%$ of silt and $15.4 \%$ of clay. The spatial distribution of soil use was made using the panchromatic image, obtained from the QuickBird satellite with $60 \mathrm{~cm}$ of pixel resolution (Figure 1). However, the main differences between the two SHB occur in areas with riparian forest $112.2 \%$ in SHB 140 and $2.4 \%$ in SHB 80 ) and in wetlands (15.3\% in SHB 80 and 5.3 $\%$ on SHB 140).

The relief information was extracted from the digital elevation model of $5 \mathrm{~m}$ pixel resolution, generated with planialtimetric survey data with real-time kinematic positioning apparatus (RTK).

The form factor (Kf) was calculated by the division between the average length of the small river basin and the axial length; according to Equation 1.

$$
\begin{aligned}
& K f=\frac{\mathrm{A}}{\mathrm{L}} \\
& \mathrm{Kf}=\text { Form factor } \\
& \mathrm{A}=\text { Watershed area }\left(\mathrm{km}^{2}\right) \\
& \mathrm{L}=\text { Total length of the watershed }(\mathrm{km}) \\
& \text { The coefficient of compactness }(\mathrm{KC})
\end{aligned}
$$
was obtained from the division between the real perimeter of the small hydrographic basin and the perimeter of an imaginary circle with an area equal to that of the small hydrographic basin according to Equation 2.

$$
K c=0,28 \times \frac{\mathrm{P}}{\sqrt[2]{A}}
$$

$K c=$ Coefficient of compactness

$P=$ Perimeter of the small basin $(\mathrm{km})$

$A=$ Area of the small basin $\left(\mathrm{km}^{2}\right)$

The data of Average concentration time and Average peak time were calculated in each SHB when 168 pluviometric events were analyzed.

In order to evaluate the contribution of the surface runoff relief (ES). Equation 3.

$$
\begin{aligned}
& R r=\frac{A m p l_{a}}{L t} \\
& R r=\text { relief ratio }\left(\mathrm{m} \mathrm{km}^{-1}\right) \\
& A m l_{a}=\text { Altimetric range }(\mathrm{m}) \\
& L t=\text { Total length of perennial and }
\end{aligned}
$$
intermittent watercourses $(\mathrm{km})$ 
Following. the drainage density of each SHB was calculated whose value is attributed from the relation between the total length of the channels and total area of the basin. according to Equation 4.

$$
\begin{aligned}
& D_{d}=\frac{C_{t}}{A_{t}} \\
& D_{d}=\text { Drainage density }(\mathrm{km}) \\
& \mathrm{C}_{\dagger}=\text { Total channel length }(\mathrm{km}) \\
& \mathrm{A}_{\dagger}=\text { Total basin area }\left(\mathrm{km}^{2}\right)
\end{aligned}
$$

The roughness index provides values that are attributed to the drainage capacity of a SHB in events of high precipitation and rapid floods. As the values obtained are larger, the greater the probability of flooding. The index was calculated according to Equation 5.

$$
\begin{aligned}
& I_{r}=\operatorname{Ampl}_{M} x D_{d} \\
& I_{r}=\text { Roughness index }
\end{aligned}
$$

$\mathrm{Ampl}_{\mathrm{M}}=$ Maximum altimetric range $(\mathrm{m})$ $D_{d}=$ Drainage density $(\mathrm{km})$
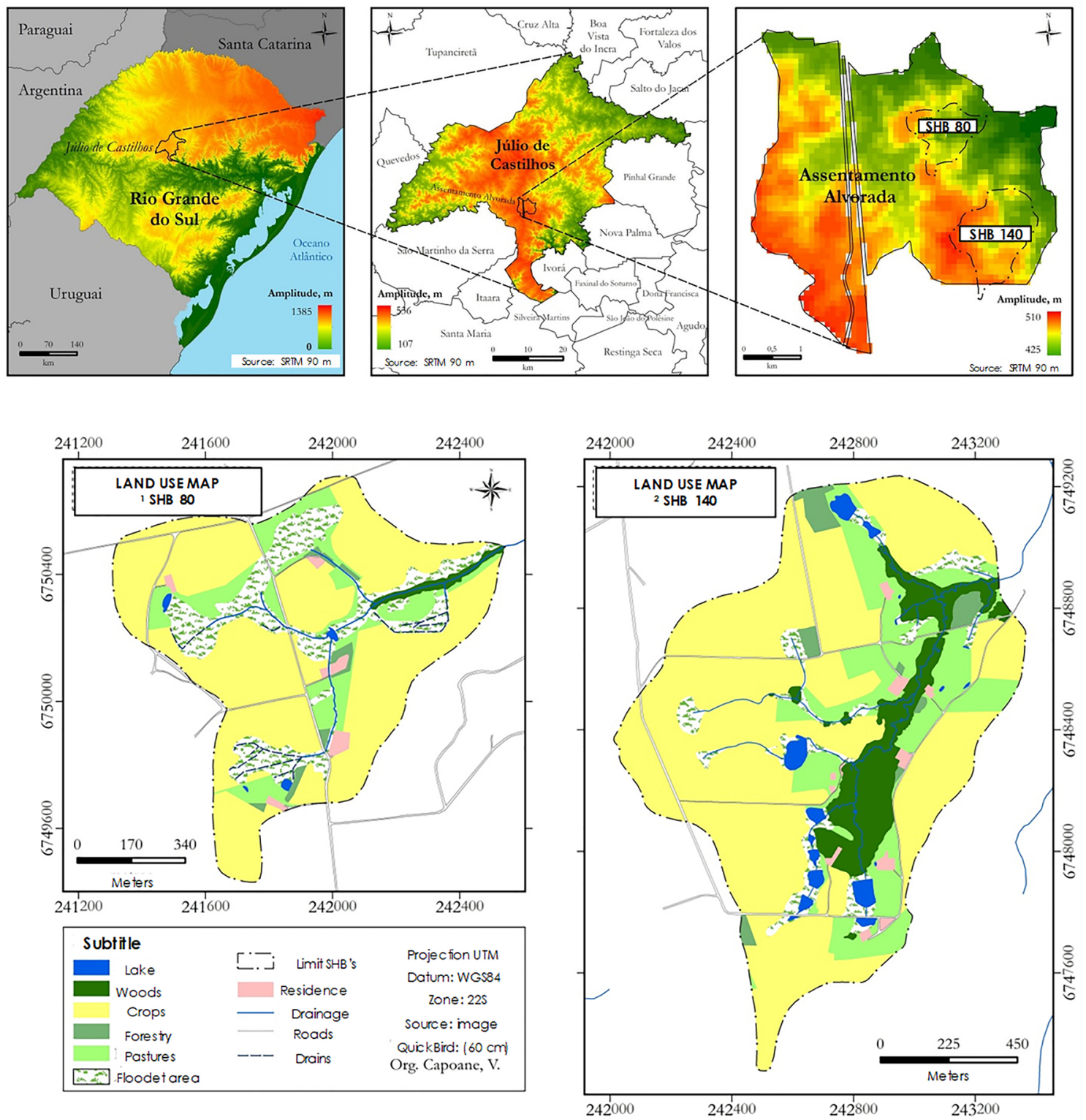

Figure 1.Distribution of land uses in the two small river basins. Alvorada Agrarian Reform Settlement in Júlio de Castilhos. Rio Grande do Sul. Brazil

ISmall Hydrographic Basin 80; 2 Small Hydrographic Basin 140 
Table 1. Classes of slope and morphometric variables obtained from the two small hydrographic basins. Júlio de Castilhos / RS

\begin{tabular}{lcc}
\hline \multirow{2}{*}{ Parameters } & \multicolumn{2}{c}{ Small Hydrographic Basin (SHB) } \\
\cline { 2 - 3 } & SHB 80 & SHB 140 \\
\hline Classes of slopes (\%) & \multicolumn{3}{c}{ Area (ha) } \\
\hline $0-3$ (mild) & 10.1 & 10.3 \\
$3-6$ (gently corrugated) & 20.6 & 27.3 \\
$6-12$ (corrugated) & 3.2 & 63.4 \\
$12-20$ (strong corrugated) & 16.7 & 43.5 \\
\hline
\end{tabular}

Morphometric variables

\begin{tabular}{|c|c|c|}
\hline Basin area (ha) & 79.6 & 144.5 \\
\hline Basin perimeter (m) & 4.171 .3 & 5.308 .4 \\
\hline $\operatorname{LW}^{(1)}(\mathrm{m})$ & 3876.0 & 5118.0 \\
\hline$L^{(2)}(\mathrm{m})$ & 51.5 & 71.0 \\
\hline $\operatorname{Sen} \theta(3)$ & 0.077 & 0.089 \\
\hline Order of waterways & $3^{\circ}$ & $3^{\circ}$ \\
\hline Drainage density $\left(\mathrm{km} \mathrm{km}^{-2}\right)$ & 4.87 & 3.54 \\
\hline Lower quota (m) & 431 & 440 \\
\hline Upper quota (m) & 485 & 506 \\
\hline Altimetric range (m) & 54 & 66 \\
\hline Basin relief relation & 13.93 & 12.89 \\
\hline Form Factor & 1.34 & 1.31 \\
\hline Coefficient of compactness & 0.47 & 0.45 \\
\hline Roughness index & 0.26 & 0.23 \\
\hline Average concentration time (min)* & 83 & 55 \\
\hline Average peak time (min)* & 206 & 143 \\
\hline
\end{tabular}

'Total length of perennial and intermittent watercourses; ${ }^{2}$ Result of the average ramp length; ${ }^{3}$ Sine of weighted average slope

* Data obtained from 168 precipitation events

In each SHB a pluviograph and three rain gauges were installed. In the SHB 80 a datalogger (SL pnv 2000) was connected to the pluviograph to record the events $15 \mathrm{~min}$ intervals). At SHB 140, near the exudation, an automatic meteorological station (Danvis, Vantage Pro 2) was installed, which captured readings at 10 minutes intervals. The flow of both SHB was obtained with the help of two Parshalls gutters of critical widths equal to 1.22 and 1.52 m; for SHB 80 (242536 E; 67504905 S) and SHB 140 (243275 E; 6748887 S) respectively. Both variables were constantly recorded by turbidity and level sensors coupled to a datalogger (5 min intervals). The meteorological and water flow records were made as of 07/31/2010 and were extended until $12 / 31 / 2012$. Based on the straight-line method recommended by Chow et al. (1998), the volume of the surface flow and, consequently, the base flow were obtained. For the separation of the flow, the method described by Tucci (2002) was used.

Suspended sediment concentration was obtained from the collection of 261 samples from
12 rainfall events at SHB 80 and, from 315 samples from 13 rainfall events at SHB 140, collected with a $\mathrm{DH} 48$ (turbidimeters) sampler. For quantification of the sediment transported by bottom trawl gear, the BLM-84 sampler was used, with a mesh of $250 \mu \mathrm{m}$. The number of subsamples, as well as the sampling time in each vertical, varied as a function of the flow aiming not to limit the flow of the runoff by obstruction of the mesh. The collections were performed in three events totaling 19 in SHB 80, and 38 samples in SHB 140. Kinetic energy was calculated in each rainfall event according to Wischmeier \& Smith (1978). The results of the sediment production were obtained through the sum of the solid discharge in suspension and the solid discharge in trawl. The concentration of suspended sediments was determined by the greenhouse evaporation method at $105{ }^{\circ} \mathrm{C}$ (NTU - 39 Nephelometric Turbidity Unit).

Statistical analysis of the data was based on descriptive statistics. Taking into account the accumulated indicators, average, standard deviation, standard error and variance of rainfall 
values, total/superficial and base flow, maximum intensity of the event in one hour, maximum concentration of suspended sediment, sediment production by bottom trawl, sediment production in suspension for turbidity, sediment production by key flow curve, sediment production in mean suspension in both methods and sediment production total. Regression analysis was applied to rainfall versus runoff values, rainfall versus kinetic energy and rainfall versus sediment yield.

\section{Results and Considerations}

Rainfall and contribution to runoff

The surface flow values presented in the specific flow form were always higher in SHB 80 than in SHB 140, presenting a superiority corresponding to 43.25; 45.20 and $50.10 \%$ in 2010 , 2011 and 2012, respectively (Table 2). The lower surface area of the SHB 80 although providing smaller rainfall capture area provided higher ES values. For Santos et al. (2012) the watershed area is directly related to the amount of water produced as a runoff. These observations are important, since ES is dependent on other factors such as spatialization and use of the areas. However, the baseline (EB) values did not show the same performance, since the differences observed in both SHB were less expressive.

Table 2. Descriptive statistics of the variables: rainfall. total / superficial and base flow. monitored in the small hydrographic basins. Júlio de Castilhos / RS

\begin{tabular}{|c|c|c|c|c|c|c|c|c|c|c|}
\hline \multirow[t]{2}{*}{ Variable } & \multicolumn{2}{|c|}{$\begin{array}{c}\text { Accumulated } \\
\text { (mm) }\end{array}$} & \multirow{2}{*}{\multicolumn{2}{|c|}{$\begin{array}{c}\text { Average } \\
(\bar{x}) \\
\text { SHB } 80 \text { SHB } 140\end{array}$}} & \multicolumn{2}{|c|}{$\begin{array}{c}\text { Standard } \\
\text { Deviation }(\sigma)\end{array}$} & \multicolumn{2}{|c|}{ Standard Error ( \pm ) } & \multicolumn{2}{|c|}{ Variance $\left(\sigma^{2}\right)$} \\
\hline & SHB $80^{5}$ & SHB $140^{6}$ & & & SHB 80 & SHB 140 & SHB 80 & SHB 140 & SHB 80 & SHB 140 \\
\hline \multicolumn{11}{|c|}{, } \\
\hline $\mathrm{Pp}^{1}$ & 475.50 & 354.70 & 23.78 & 35.47 & 21.65 & 29.31 & 4.84 & 9.27 & 468.77 & 859.12 \\
\hline $\mathrm{ET}^{2}$ & 117.50 & 80.30 & 5.88 & 8.03 & 8.47 & 7.87 & 1.90 & 2.49 & 71.82 & 61.90 \\
\hline$E S^{3}$ & 57.10 & 32.40 & 2.86 & 3.24 & 4.63 & 3.86 & 1.03 & 1.22 & 21.40 & 14.86 \\
\hline $\mathrm{EB}^{4}$ & 60.40 & 47.90 & 3.02 & 4.79 & 3.89 & 4.26 & 0.87 & 1.35 & 15.17 & 18.11 \\
\hline \multicolumn{11}{|c|}{2011 .. } \\
\hline $\mathrm{Pp}$ & 1170.80 & 1097.70 & 25.46 & 28.15 & 16.45 & 17.72 & 2.43 & 2.84 & 270.53 & 314.16 \\
\hline ET & 206.00 & 160.60 & 4.48 & 4.12 & 5.01 & 4.16 & 0.74 & 0.67 & 25.15 & 17.30 \\
\hline ES & 108.40 & 59.40 & 2.36 & 1.52 & 3.38 & 2.02 & 0.50 & 0.32 & 11.41 & 4.08 \\
\hline$E B$ & 97.60 & 101.20 & 2.12 & 2.59 & 1.79 & 2.34 & 0.26 & 0.38 & 3.19 & 5.49 \\
\hline \multicolumn{11}{|c|}{$2012 \ldots \ldots$} \\
\hline $\mathrm{Pp}$ & 1089.40 & 1178.30 & 45.39 & 40.63 & 15.69 & 17.37 & 3.20 & 3.23 & 246.17 & 301.76 \\
\hline ET & 170.60 & 119.40 & 7.11 & 4.98 & 5.85 & 3.94 & 1.20 & 0.73 & 34.28 & 14.64 \\
\hline ES & 92.40 & 47.10 & 3.85 & 1.96 & 4.18 & 2.08 & 0.85 & 0.39 & 17.44 & 3.86 \\
\hline EB & 78.20 & 72.30 & 3.26 & 3.01 & 2.61 & 2.28 & 0.53 & 0.42 & 6.82 & 5.01 \\
\hline
\end{tabular}

' Rainfall; ${ }^{2}$ Total flow; ${ }^{3}$ Surface runoff; ${ }^{4}$ Base flow (mm); ${ }^{5}$ Small basin 80; ${ }^{6} \mathrm{Small}$ basin 140

* Values obtained from 168 rainfall events

In the first monitoring period, EB values were $20.69 \%$ higher in SHB 80 than those found in SHB 140. In 2011, PB values in SHB 80 were lower than those in SHB 140 and corresponded to a difference of $3.56 \%$. In 2012, again, the EB values were higher in SHB 80, but only in $7.54 \%$. From the accumulated values of rainfall $(\mathrm{Pp})$ in the years 2010, 2011 and 2012, 12.70, 8.34 and $7.18 \%$ were transformed into EB in SHB 80 and 13.50, 9.22 and $6.13 \%$ in SHB 140 respectively.

Regarding the balance of the hydrological dynamics in the SHB, the ES and EB accumulated in 2010, 2011 and 2012 values that corresponded to 117.50 and $80.30 \mathrm{~mm} ; 206$ and $160.60 \mathrm{~mm}$ and 170.60 and $119.40 \mathrm{~mm}$ in SHB 80 and SHB 140, respectively. The difference between total rainfall and runoff values was attributed to losses such as evapotranspiration, deep infiltration and soil water storage. As a result, it was found that the highest losses due to total flow (ET) and ES occurred in SHB 80 and the highest water storage occurred in SHB 140.

In Figure 2 the regression equations and their respective adjustments were plotted, which were given in a directly proportional way, being typified in linear, polynomial and potential. As shown in Figure 1a, in 2010 the values were adjusted in positive linear trend lines $(y=a+b x)$, with determination coefficient $\left(R^{2}\right)$ in the SHB 80 equal to $86 \%$ and in the SHB 140 equal to $73 \%$.

In 2011 the equation was linear, only in SHB 80 with $\left(R^{2}\right)$ of $53 \%$ (Figure $1 \mathrm{~b}$ ), whereas in SHB 140 it was polynomial and $\left(R^{2}\right)$ was $47 \%$. In 2012 , the values were adjusted in potential trend 
lines in SHB 80 with $\left(R^{2}\right)$ of $42 \%$ and in SHB 140 of linear type with $\left(R^{2}\right)$ of $26 \%$. In other words, the regression equations generated low $\left(R^{2}\right)$ values in the years 2011 and 2012, but remained higher in SHB 80 during the whole monitoring period.

These results are evidenced by the dispersion of the points in Figure $2 b$ and $2 c$, a fact that associated with accumulated $\mathrm{Pp}$ between
1089.70 and 1178.70 contributed with the lowest relation between $\mathrm{Pp}$ and $\mathrm{ES}$. These observations are in line with the considerations of Sari et al. (2016) where the authors postulate that the flow tends to be larger as the rainfall increases. However, this elevation does not occur linearly, since they are dependent on other factors.
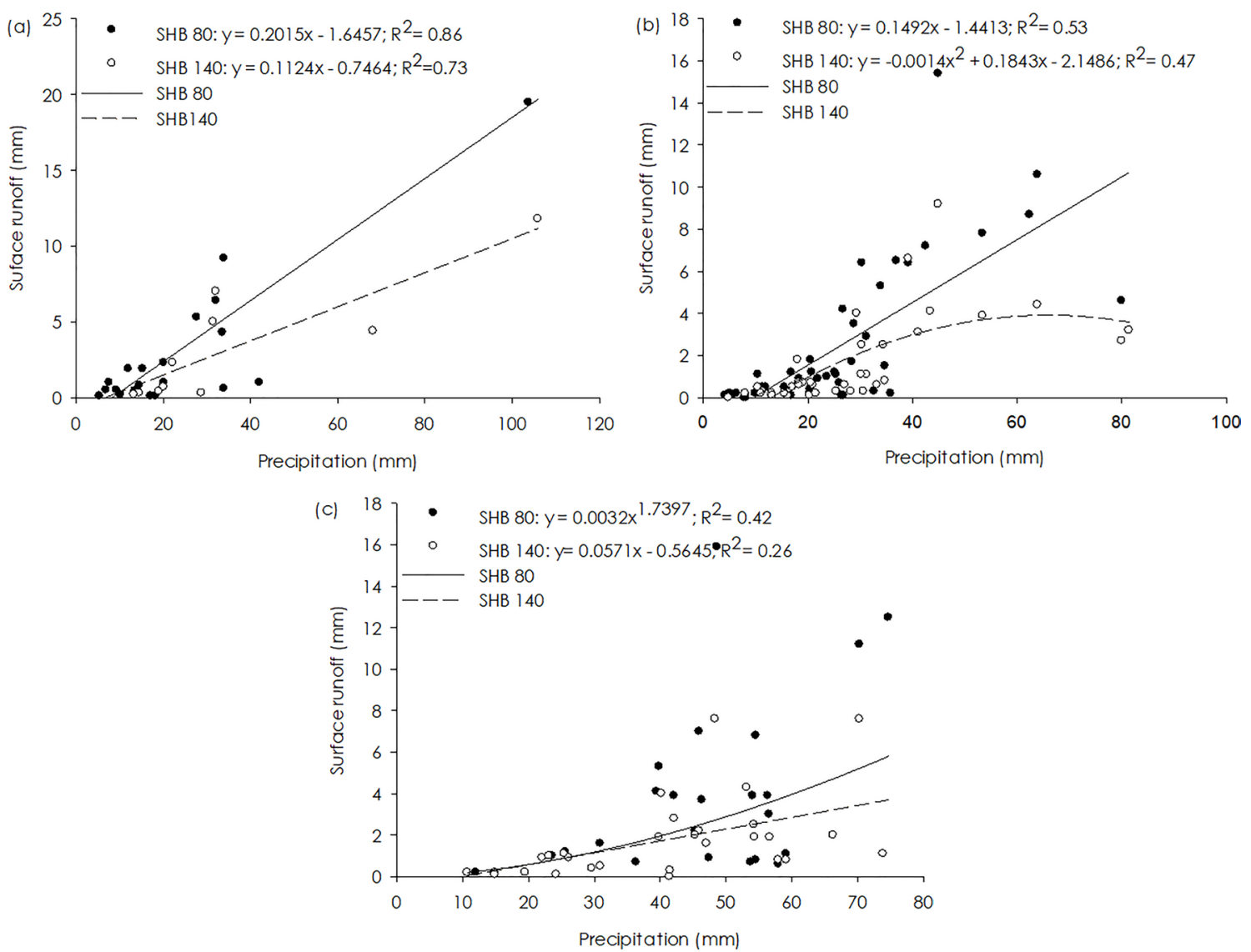

Figure 2. Relationship between rainfall and surface runoff of the monitoring carried out in the years 2010 (a), 2011 (b) and 2012 (c). Júlio de Castilhos / RS

- Small Hydrographic Basin 80 O Small Hydrographic Basin 140

Therefore, the morphometric variables of both SHB were evaluated with greater precision. It should be emphasized that these are two paired SHB with similar soil and use characteristics, but some considerations will be made regarding relief, altimetric amplitude and drainage density (Table 1) and use of the SHB (Figure 1).

Regarding the relief, in both SHB a lower area of mild and gently corrugated areas, which corresponded to $38.56 \%$ in SHB 80 and $26.02 \%$ in SHB 140 was noticed. These percentages were not sufficient to explain the lower values of ES, mainly in relation to SHB 80. In the same way, one could expect higher ES values in SHB 140, due to the larger area fraction (73.98\%) corresponding to the corrugated and strong corrugated relief.

The contribution of the relief of each SHB when related to altitude, provided $R_{r}$ values that corresponded to 13.93 and $12.89 \mathrm{~km}^{-1}$ for SHB 80 and SHB 140, respectively. The value of $R_{r}$ in SHB 80 was lower, only $3 \%$ from the value found in SHB 140. However, it is justified due to the lower altimetric amplitude and the smaller distance from the main riverbed.

At SHB 80 the drainage density $\left(D_{d}\right)$ was $4.87 \mathrm{~km} \mathrm{~km}^{-2}$ and in SHB 140 it was $3.54 \mathrm{~km}$ $\mathrm{km}^{-2}$. These values obtained in those SHB classify them as having a high drainage capacity due 
to their present values greater than $3.5 \mathrm{~km} \mathrm{~km}^{-2}$ (Rocha et al., 2014). The values obtained confirm the lower ability of SHB 80 to resist ES than SHB 140. The value of $D_{d}$ is inversely proportional to the extent of ES, which may partly explain the lower ability of SHB 80 to retard ES, since it has a smaller extension (Table 1). Other factors that support the justification of the highest observed ES values in SHB 80 are due to the higher values of concentration time and peak time that corresponded to $83 \mathrm{~min}(\sigma=34.03)$ and $206 \mathrm{~min}$ $(\sigma=67,71)$ respectively.

The elongated form observed in both SHB associated with $D_{d}$ values confirms the lower capacity for flooding and the permanence of large water volumes for longer periods under the surface. According to Ferreira et al. (2012) the shape of the basin directly influences the time of concentration, that is, the necessary time for all the water to contribute to its exit after a Pp event. It is possible to observe the adjustment of the equations obtained from the relations between Pp (mm) and PS ( $\left.\mathrm{Mg} \mathrm{ha}^{-1}\right)$, as well as the relationship between $E_{C}\left(M^{\prime} \mathrm{km}^{-2}\right)$ and $P S(M g$ $\mathrm{ha}^{-1}$ ) (Figure 3). Directly proportional equational adjustments, typified by linear, polynomial and potential lines were observed. In Figure $3 a$, the equation between Pp versus PS of the SHB in the second period of 2010, assigned positive linear lines with $R^{2}$ values in the order of 87 and $80 \%$ for SHB 80 and SHB 140, respectively. Similarly to $E_{C}$ versus $P S, R^{2}$ values were equal to $88 \%$ for SHB 80 and $81 \%$ for SHB 140 (Figure 3b).
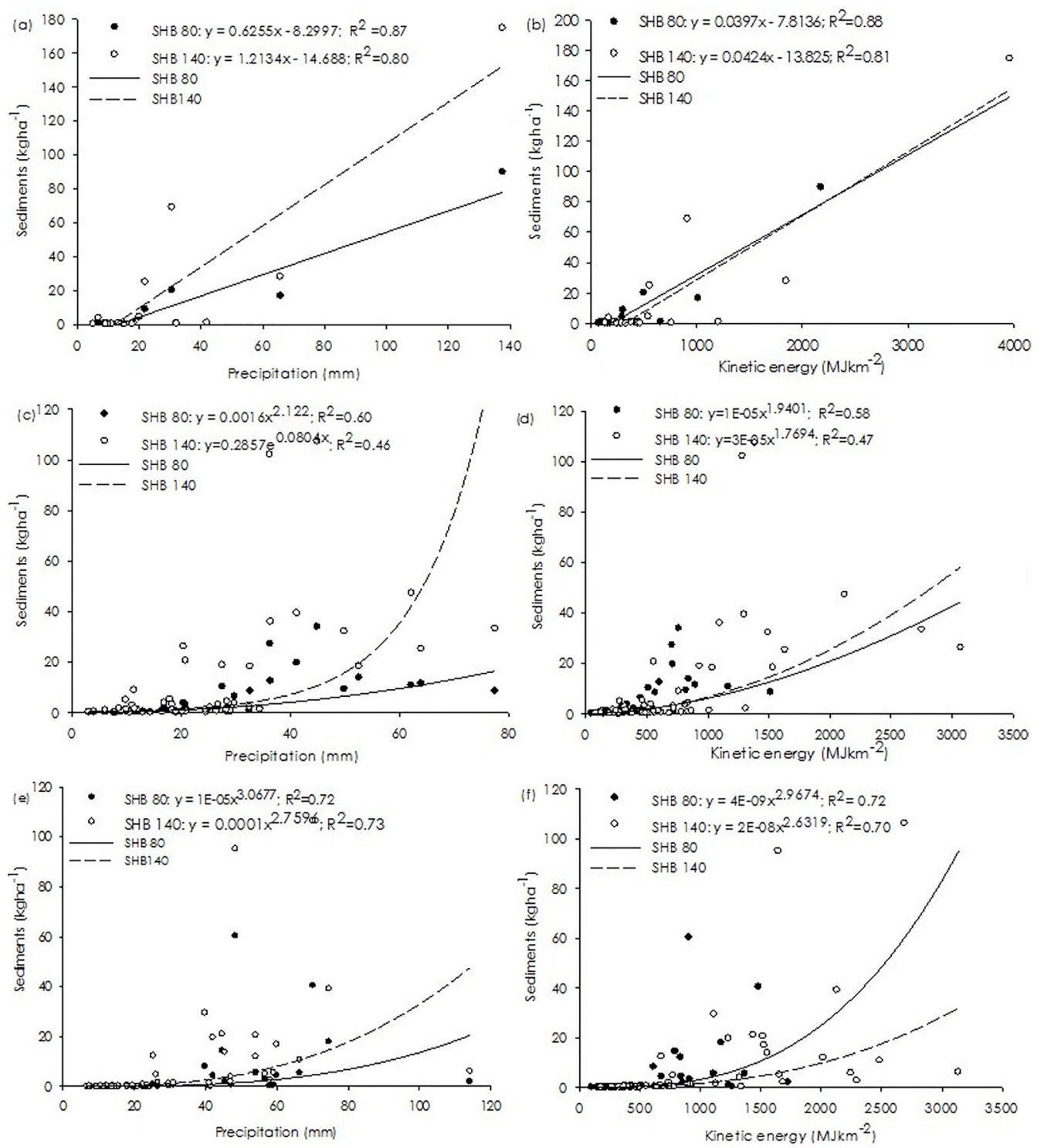

Figure 3. Relationship between rainfall, kinetic energy and sediment production obtained from the monitoring conducted in the years 2010 (a, b), 2011 (c, d) and 2012 (e, f). Júlio de Castilhos / RS

- Small Hydrographic Basin 80, o Small Hydrographic Basin 140 
The PS detected occurred from events of $\mathrm{Pp} \geq 5,1 \mathrm{~mm}(07 / 10)$ which generated values of $E_{C}$ and $P S$ corresponding to $76 \mathrm{MJ} \mathrm{Km}^{-2}$ and $0.233 \mathrm{Mg} \mathrm{ha}^{-1}$ in SHB 80 and 138,335 $\mathrm{MJ} \mathrm{Km}^{-2}$ and $0.287 \mathrm{Mg} \mathrm{ha}^{-1}$ in SHB 140, respectively (Figure 3a and $3 \mathrm{~b}$ ). It should be noted that in September alone, $271.95 \mathrm{~mm}$ accumulated, corresponding to $44.84 \%$ above the monthly historical average. In a single Pp event recorded on 01/09, 137.55 $\mathrm{mm}$ accumulated, which generated high values of EC and PS corresponding to 2.175,73 $\mathrm{MJ} \mathrm{Km}^{-2}$ and $89,777 \mathrm{Mg} \mathrm{ha}^{-1}$ in SHB 80, and 3.960,89 MJ $\mathrm{Km}^{-2}$ and $174,617 \mathrm{Mg} \mathrm{ha}^{-1}$ in SHB 140, respectively.

The PS in 2011 were higher, and the equational adjustment was by $y=a x^{n}$ with $R^{2}$ equal to $60 \%$ in SHB 80 (Figure 3c), and in SHB 140 by $y=e^{b x}$ with $R^{2}$ less than and equal to $46 \%$ (Figure $3 d$ ). Both models showed that, in view of the increase in Pp and Ce, PS increased. These results are in line with those found by Oliveira et al. (2015), which found a direct relationship between the largest floods and the increase of sediment transport and disintegration energy.

The PS detected occurred from events of $\mathrm{Pp} \geq 3.0 \mathrm{~mm}(07 / 08)$ that generated values of EC and PS that corresponded to 43,165 MJ $\mathrm{Km}^{-2}$ and $0.067 \mathrm{Mg} \mathrm{ha}^{-1}$ in SHB 80 and 75,581 MJ $\mathrm{Km}^{-2}$ and $0.221 \mathrm{Mg} \mathrm{ha}^{-1}$ in SHB 140, respectively (Figure $3 \mathrm{c}$ and $3 \mathrm{~d}$ ). The lower $\mathrm{Pp}$ that triggered the PS was justified in part by the antecedent soil moisture. In July, Pp was equal to 198.9 $\mathrm{mm}$, which corresponded to $28.81 \%$ above the monthly historical average. In August, a higher Pp than the monthly historical average, which corresponded to an increase of $33.28 \%$ was also recorded. The highest $\mathrm{Pp}$ event recorded in August generated values of EC and PS that corresponded to $759.99 \mathrm{MJ} \mathrm{Km}^{-2}$ and $33,907 \mathrm{Mg}$ $\mathrm{ha}^{-1}$ in SHB 80 and $1383.55 \mathrm{MJ} \mathrm{Km}^{-2}$ and 107,452 $\mathrm{Mg} \mathrm{ha}^{-1}$ in SHB 140, respectively (Figure $3 \mathrm{C}$ and 3d). In 2012 the PS detected occurred from events of $\mathrm{Pp} \geq 6.7 \mathrm{~mm}(21 / 01)$ that generated values of EC and PS that corresponded to 95,080 $\mathrm{MJ} \mathrm{Km}^{-2}$ and $0,010 \mathrm{Mg} \mathrm{ha}^{-1}$ in SHB 80 and 173,093 $\mathrm{MJ} \mathrm{Km}^{-2}$ and $0.073 \mathrm{Mg} \mathrm{ha}^{-1}$ in SHB 140, respectively (Figure $3 \mathrm{e}$ and $3 \mathrm{f}$ ).

The greatest resistance to the triggering of the erosive processes is due to the inverse reasons to those occurred in 2011 . Soil moisture content was likely to be low, as irrigation is not practiced in monitored areas, and the October 2011 Pp events that extended to September 2012 remained well below the historical average.

Otherwise, the highest rates of infiltration occur in periods of drought, consequently, the lowest ES rates generating lower PS losses were observed. Thus, the highest values of PS between events, greater than in the events themselves, accumulated total sediment losses in SHB 80 and SHB 140 equal to 7.4 and $16.5 \mathrm{Mg} \mathrm{km}^{-2}$ year 1, respectively. It is important to highlight that the main difference between the SHB is due to the wetlands (banhados). In SHB 80 there is a larger area of banhado, which is 4.51 ha higher than that in SHB 140. These sites, although they generate greater surface runoff because they remain saturated for long periods, may be contributing to the retention of large amounts of sediment through palustrine and dense vegetation (Verstraeten et al., 2006).

In general, the results confirm that, as $\mathrm{Pp}$ increased the EC and the PS also increased in the SHB, in the same way, that the highest PS occurred in SHB 140. These results agree with those found by Cabral et al. (2013) and Medeiros \& Silva (2014) who observed higher PS as Pp increased.

\section{Sediment losses in small watersheds}

The PS estimated in the SHB accumulated 455,$578 ; 828,069$ and $626,806 \mathrm{Mg} \mathrm{ha}^{-1}$ in 2010; 2011 and 2012, respectively. The PS in SHB 80 was $145,828 \mathrm{Mg} \mathrm{ha}^{-1}(\bar{x}=7,675 ; \sigma=20,721)$ and in PHB $140309.750 \mathrm{Mg} \mathrm{ha}^{-1}(\bar{x}=16,303 ; \sigma=41,923)$. In 2011, the highest PS of the monitoring were recorded, with PBH $80209.630 \mathrm{Mg} \mathrm{ha}^{-1}(\bar{x}=4,031$; $\sigma=7,017)$ and in PHB $140618,439 \mathrm{Mg} \mathrm{ha}^{-1}(\bar{x}=$ $11,893 ; \sigma=22,561)$. The PS in 2012 accumulated $187,571 \mathrm{Mg} \mathrm{ha}^{-1}(\bar{x}=3,908 ; \sigma=10,732)$ in SHB 80 and $439,235 \mathrm{Mg} \mathrm{ha}^{-1}$ year $^{-1}(\bar{x}=9,151 ; \sigma=21,159)$ in SHB 140.

In more details, Table 3 shows the calculated and estimated PS values in both SHB. The values of the maximum intensity of the precipitation occurred in one hour (I max $1 \mathrm{~h}$ ) obtained in SHB 80 did not remain higher in all the monitoring observations due to the lower number of $\mathrm{Pp}$ events recorded in 2010, which 
corresponded to $50 \%$ of those registered in SHB 140.

Although the records of the $\mathrm{Pp}$ events were smaller, it was found that the values of maximum suspended sediment concentration $\left(\mathrm{CSS}_{\text {Max }}\right)$ in SHB 140 were always higher than the values found in SHB 80. The values of $\mathrm{CSS}_{\text {Max }}$ in SHB 140, were higher at 78.69 (2010); 76.32 (2011) and 78.52 (2012) percent of SHB 80 values. The larger area covered by natural reservoirs in SHB 80 (Figure 1) is contributing more efficiently to sediment retention, although CSS $_{\text {Max }}$ results express high variation. However, they are shown to be smaller in SHB 80. The importance of reservoirs in sediment retention was also observed by Pinheiro et al. (2013), since the maximum concentration in general is retained, providing CSS damping, according to the authors, the amount of sediment delivered downstream of the reservoir is almost always below the production potential of the basin.

Table 3. Descriptive statistics of the hydrological and sedimentological variables obtained in the small hydrographic basins. Júlio de Castilhos / RS

\begin{tabular}{|c|c|c|c|c|c|c|c|c|}
\hline \multirow[t]{2}{*}{ Variável } & \multicolumn{2}{|c|}{$\begin{array}{l}\text { Average } \\
(\bar{x})\end{array}$} & \multicolumn{2}{|c|}{$\begin{array}{l}\text { Standard Deviation } \\
(\sigma)\end{array}$} & \multicolumn{2}{|c|}{$\begin{array}{l}\text { Standard Error } \\
( \pm)\end{array}$} & \multicolumn{2}{|c|}{$\begin{array}{l}\text { Variance } \\
\left(\sigma^{2}\right)\end{array}$} \\
\hline & SHB $80^{8}$ & SHB $140^{\circ}$ & SHB 80 & SHB 140 & SHB 80 & SHB 140 & SHB 80 & SHB 140 \\
\hline & & & & & 2010. & & & ....... \\
\hline$I \max 1 \mathrm{~h}\left(\mathrm{~mm} \mathrm{~h}^{-1}\right)^{1}$ & 5.60 & 10.42 & 3.33 & 4.25 & 0.74 & 1.34 & 11.09 & 18.05 \\
\hline $\mathrm{CSS}_{\operatorname{Max}}\left(\mathrm{mg} \mathrm{L}^{-1}\right)^{2}$ & 160.29 & 752.10 & 114.84 & 618.10 & 25.68 & 195.46 & 13.189 & 382.048 \\
\hline PSA (Mg evento-1) $)^{3}$ & 0.009 & 0.253 & 0.019 & 0.362 & 0.004 & 0.115 & 0.0004 & 0.131 \\
\hline $\mathrm{PS}_{\text {Turb. }}(\mathrm{Mg} \text { evento-1 })^{4}$ & 0.582 & 4.402 & 1.107 & 5.298 & 0.247 & 1.676 & 1.225 & 28.074 \\
\hline$P S A+P S_{\text {Turb. }}$ & 0.590 & 4.656 & 1.124 & 5.645 & 0.251 & 1.785 & 1.263 & 31.870 \\
\hline PSQ (Mg evento-1 $)^{5}$ & 0.517 & 3.736 & 1.050 & 4.717 & 0.235 & 1.492 & 1.103 & 22.250 \\
\hline $\mathrm{PSS}_{\text {Média }}(\mathrm{Mg} \text { evento-1 })^{6}$ & 0.549 & 4.069 & 1.059 & 4.998 & 0.237 & 1.581 & 1.122 & 24.980 \\
\hline \multirow{2}{*}{$\mathrm{PS}_{\text {Total }}\left(\mathrm{PSA}+\mathrm{PSS}_{\text {Média }}\right)^{7}$} & 0.558 & 4.323 & 1.078 & 5.349 & 0.241 & 1.691 & 1.162 & 28.611 \\
\hline & & & & & 2011 & & & ..... \\
\hline I max $1 \mathrm{~h}\left(\mathrm{~mm} \mathrm{~h}^{-1}\right)$ & 11.70 & 9.19 & 9.92 & 7.60 & 1.46 & 1.22 & 98.47 & 57.72 \\
\hline $\mathrm{CSS}_{\operatorname{Max}}\left(\mathrm{mg} \mathrm{L}^{-1}\right)$ & 156.79 & 662.30 & 159.17 & 523.16 & 23.47 & 83.77 & 25.333 & 273.694 \\
\hline PSA (Mg evento-1) & 0.005 & 0.118 & 0.012 & 0.293 & 0.002 & 0.047 & 0.0001 & 0.086 \\
\hline $\mathrm{PS}_{\text {Turb. }}(\mathrm{Mg}$ evento-1) & 0.316 & 2.117 & 0.487 & 3.102 & 0.072 & 0.497 & 0.237 & 9.621 \\
\hline$P S A+P S_{\text {Turb }}$ & 0.321 & 2.235 & 0.498 & 3.375 & 0.073 & 0.540 & 0.248 & 11.388 \\
\hline PSQ (Mg evento-1) & 0.327 & 1.649 & 0.638 & 3.368 & 0.094 & 0.539 & 0.407 & 11.341 \\
\hline $\mathrm{PSS}_{\text {Média }}(\mathrm{Mg}$ evento-1) & 0.321 & 1.883 & 0.557 & 3.194 & 0.082 & 0.511 & 0.310 & 10.201 \\
\hline \multirow[t]{2}{*}{$P_{\text {Total }}\left(P S A+P S S_{\text {Médial }}\right)$} & 0.326 & 2.002 & 0.568 & 3.479 & 0.310 & 0.557 & 0.323 & 12.105 \\
\hline & & & & & $2012 \ldots \ldots$ & & ... & \\
\hline I max $1 \mathrm{~h}\left(\mathrm{~mm} \mathrm{~h}^{-1}\right)$ & 18.16 & 13.81 & 14.75 & 10.37 & 3.01 & 1.93 & 217.43 & 107.50 \\
\hline $\mathrm{CSS}_{\operatorname{Max}}\left(\mathrm{mg} \mathrm{L}^{-1}\right)$ & 90.51 & 421.37 & 77.96 & 410.48 & 15.91 & 76.22 & 6.078 & 168.496 \\
\hline PSA (Mg evento-1) & 0.018 & 0.190 & 0.041 & 0.490 & 0.008 & 0.091 & 0.002 & 0.240 \\
\hline $\mathrm{PS}_{\text {Turb. }}(\mathrm{Mg}$ evento-1) & 0.286 & 1.234 & 0.600 & 1.682 & 0.123 & 0.312 & 0.360 & 2.829 \\
\hline$P S A+P S_{\text {Turb }}$ & 0.303 & 1.424 & 0.629 & 2.129 & 0.128 & 0.395 & 0.396 & 4.534 \\
\hline PSQ (Mg evento-1) & 0.839 & 2.306 & 1.659 & 4.781 & 0.339 & 0.888 & 2.753 & 22.858 \\
\hline PSS $_{\text {Média }}\left(\right.$ Mg evento-1) $^{-1}$ & 0.562 & 1.770 & 1.067 & 3.172 & 0.218 & 0.589 & 1.137 & 10.061 \\
\hline $\mathrm{PS}_{\text {Total }}\left(P S A+P S S_{\text {Média }}\right)$ & 0.580 & 1.960 & 1.106 & 3.655 & 0.226 & 0.679 & 1.224 & 13.357 \\
\hline
\end{tabular}

Otherwise, Minella et al. (2011) also postulate that the relationship between the net flow and CSS presents complex temporal patterns, mainly due to the distribution factors of precipitation, geomorphology, use and soil management. These observations are important because even though the management of the production areas is similar - and also the largest areas covered by exotic and riparian forests were observed in SHB 140, which together represent 15.7 ha more than in SHB 80 (Figure 1) - these were not sufficient to provide lower CSS $_{\text {Max }}$ values.

Similar performance was observed in the values obtained from sediment production by bottom trawl (PSA). The PSH values of SHB 80 were extremely lower than those found in SHB 140 in 
the years 2010, 2011 and 2012 and corresponded to $3.56 ; 4.24$ and $9.47 \%$, respectively. The natural roughness provided by the forest areas and the temporary roughness from the cropping areas, as well as pastures, were not sufficient to ensure lower PS in the SHB 140. These observations are justified in part by the permanence of the animals in continuous grazing near the forest areas. Intense grazing reduces the vegetation's natural bus capacity as well as water filtration during more extreme ES processes. The reduction of ES, as well as the importance of forage cover provided by Johnston (2014) and Lu et al. (2013).

Turbidimetric sediment yield values (PSTurb.) in SHB 140 were extremely higher than that found in SHB 80, corresponding to $86.78 \%$ in $2010,85.07 \%$ in 2011 and $86.79 \%$ in 2012 .

The increase in rainfall directly contributes to the increase in kinetic energy, and leads to greater sediment losses in both small river basins.

The larger area occupied by natural water reservoirs contributes efficiently to the reduction of suspended sediment losses.

The watershed with larger area is more susceptible to the triggering of erosive processes than that with smaller area, in 8 (2010), 6 (2011) and 4 (2012) times.

\section{References}

Cabral, S.L., Reis, R.S., Júnior, C.R.F. 2013. Avaliação do efeito da urbanização na produção de sedimentos da bacia do rio Jacarecica/AL mediante uso de modelo hidrossedimentológico distribuído. Revista Brasileira de Ciência do Solo 37: 1073-1080.

Chow, V.T., Maidment, D.R., Mays, L.W. 1988. Applied hydrology. McGraw-Hill Education, New York, USA. 475p.

Ferrari, J.L., Silva, S.F., Santos, A.R., Garcia, R.F. 2013. Análise morfométrica da sub-bacia hidrográfica do córrego Horizonte Alegre, ES. Revista Brasileira de Ciências Agrárias 8: 181-188.

Ferreira, R.G., Moura, M.C.O., Castro, F.S. 2012. Caracterização morfométrica da sub-bacia do Ribeirão Panquinhas, ES. Enciclopédia Biosfera 8: 2247-2256.

Johnston, C.A. 2014. Agricultural expansion: land use shell game in the U.S. Northern Plains. Landscape Ecology 29: 81-95.

Lu, C.X., Yu, G., Xiao, Y., Xie, G.D. 2013. Wind tunnel simulation and evaluation of soil conservation function of alpine grassland in Qinghai-Tibet Plateau. Ecological Economics 86: 16-20.

Medeiros, I.C., Silva, R.M. 2014. Análise da erosão hídrica na região Semiárida da Paraíba usando o modelo Swat acoplado a um Sig. Geociência 33: $457-471$.

Minella, J.P.G., Merten, G.H., Magnago, P.F. 2011. Análise qualitativa e quantitativa da histerese entre vazão e concentração de sedimentos durante eventos hidrológicos. Revista Brasileira de Engenharia Agrícola e Ambiental 15: 13061313.

Minella J.P.G., Walling, D.E., Merten, G.H. 2008. Combining traditional monitoring and sediment source tracing techniques to assess the impact of improved land management on catchment sediment yields. Journal of Hydrology 348: 546563.

Nyssen, J., Clymans, W., Poesen, J., Vandecasteele, I., Baets, S., Haregeweyn, N., Naudts, J., Hadera, A., Moeyrsons, J., Haile, M., Deckers, J. 2009. How soil conservation affects the catchment sediment budget - A comprehensive study in the north Ethiopian highlands. Earth Surface Process 34: 216-1223.

Oliveira, L. C., Bertol, I., Barbosa, F.T., Campos, M.L., Junior, J.M. 2015. Perdas de solo, água e nutrientes por erosão hídrica em uma estrada florestal na Serra Catarinense. Ciência Florestal 25: 655-665.

Pedron, F.A., Poelking, E.L., Dalmolin, R.S.D., Azevedo, A.C., Klamt, E. 2006. Aptidão de uso da terra como base para o planejamento da utilização dos recursos naturais no município de São João do Polêsine - RS. Ciência Rural 36: 105112.

Perazzoli, M., Pinheiro, A., Kaufmann, V. 2013. Efeitos de cenários de uso do solo sobre o regime hídrico e produção de sedimentos na bacia do Ribeirão Concórdia-SC. Revista Árvore 37: 859869.

Pinheiro, E.A.R., Araújo, J.C., Fontenele, S.B., Lopes, J.W.B. 2013. Calibração de turbidímetro e análise de confiabilidade das estimativas de sedimento suspenso em bacia semiárida. Water Resources and Irrigation Management 2: 103-110.

Ran, Q., Su, D., Li, P., He, Z. 2012. Experimental study of the impact of rainfall characteristics on runoff generation and soil erosion. Journal of Hydrology 424-425: 99-111.

Rocha, R.M., Lucas, A.A.T., Almeida, C.A.P., Neto, E.L.M., Netto, A.O.A. 2014. Caracterização morfométrica da sub-bacia do rio Poxim-Açu, Sergipe, Brasil. Revista Ambiental Água 9: 276287. 
Santos, A.M., Targa, M.S., Batista, G.T., Dias, N.W. 2006. Análise morfométrica das sub-bacias hidrográficas Perdizes e Fojo no município de Campos do Jordão, SP, Brasil. Revista Ambiente \& Água - An Interdisciplinary Journal of Applied Science 7: 195-211.

Sari, V., Paiva, E.M.C.D., Paiva, J.B.D. 2016. Interceptação da chuva em diferentes formações florestais na região sul do Brasil. Revista Brasileira de Recursos Hídricos 21: 65-79.

Silva, F.G.B., Lombardi Neto, F., Primavesi, O., Crestana, S. 2010. Previsão da perda de solo na Fazenda Canchim - SP (EMBRAPA) utilizando geoprocessamento e O USLE 2D. Engenharia Sanitária e Ambiental 15: 141-148.

Silva, E.B., Nogueira, R.E., Uberti, A.A.A. 2010. Avaliação da aptidão agrícola das terras como subsídio ao assentamento de famílias rurais, utilizando sistemas de informações geográficas. Revista Brasileira de Ciência do Solo 34: $1977-$ 1990.

Souza, M.M., Gastaldini, M.C.C. 2014. Avaliação da qualidade da água em bacias hidrográficas com diferentes impactos antrópicos. Engenharia Sanitária e Ambiental 19: 263-274.

Torres, J.L.R., Fabian, A.J., Silva, A.L., Pessoa, E.J., Silva, E.C., Resende, E.F. 2008. Diagnóstico ambiental e análise morfométrica da microbacia do córrego Lanhoso em Uberaba, MG. Revista Caminhos de Geografia 9: 1-11.

Tucci, C.E.M. 2002. Regionalização de vazão. Ed. da UFRGS, Porto Alegre, Brasil. 256p.

Verstraeten, G., Poesen, J., Demarée, G., Salles, C. 2006. Long-term (105 years) variability in rain erosivity as derived from 10-min rainfall depth data for Ukkel (Brussels, Belgium): Implications for assessing soil erosion rates. Journal of Geophysical Research 111 (D22109): 1-11.

Wischmeier, W.H., Smith, D.D. 1978. Predicting rainfall erosion losses - a guide to conservative planning. Department of Agriculture, Agriculture Handbook, Washington, USDA. 58p. 